\title{
2011s-37 \\ Gas Prices Variations and Urban Sprawl: an Empirical Analysis of the 12 Largest Canadian Metropolitan Areas
}

Georges A. Tanguay, Ian Gingras

Série Scientifique
Scientific Series

Montréal

Avril 2011

(C) 2011 Georges A. Tanguay, Ian Gingras. Tous droits réservés. All rights reserved. Reproduction partielle permise avec citation du document source, incluant la notice $($.

Short sections may be quoted without explicit permission, if full credit, including $@$ notice, is given to the source.
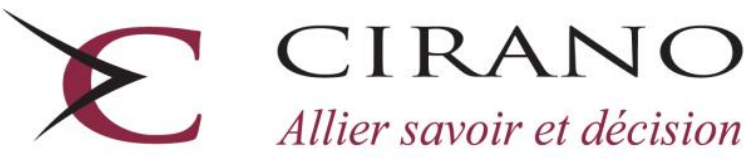

Allier savoir et décision

Centre interuniversitaire de recherche en analyse des organisations 


\section{CIRANO}

Le CIRANO est un organisme sans but lucratif constitué en vertu de la Loi des compagnies du Québec. Le financement de son infrastructure et de ses activités de recherche provient des cotisations de ses organisations-membres, d'une subvention d'infrastructure du Ministère du Développement économique et régional et de la Recherche, de même que des subventions et mandats obtenus par ses équipes de recherche.

CIRANO is a private non-profit organization incorporated under the Québec Companies Act. Its infrastructure and research activities are funded through fees paid by member organizations, an infrastructure grant from the Ministère du Développement économique et régional et de la Recherche, and grants and research mandates obtained by its research teams.

\section{Les partenaires du CIRANO}

Partenaire majeur

Ministère du Développement économique, de l'Innovation et de l'Exportation

\section{Partenaires corporatifs}

Banque de développement du Canada

Banque du Canada

Banque Laurentienne du Canada

Banque Nationale du Canada

Banque Royale du Canada

Banque Scotia

Bell Canada

BMO Groupe financier

Caisse de dépôt et placement du Québec

Fédération des caisses Desjardins du Québec

Financière Sun Life, Québec

Gaz Métro

Hydro-Québec

Industrie Canada

Investissements PSP

Ministère des Finances du Québec

Power Corporation du Canada

Raymond Chabot Grant Thornton

Rio Tinto

State Street Global Advisors

Transat A.T.

Ville de Montréal

\section{Partenaires universitaires}

École Polytechnique de Montréal

HEC Montréal

McGill University

Université Concordia

Université de Montréal

Université de Sherbrooke

Université du Québec

Université du Québec à Montréal

Université Laval

Le CIRANO collabore avec de nombreux centres et chaires de recherche universitaires dont on peut consulter la liste sur son site web.

Les cahiers de la série scientifique (CS) visent à rendre accessibles des résultats de recherche effectuée au CIRANO afin de susciter échanges et commentaires. Ces cahiers sont écrits dans le style des publications scientifiques. Les idées et les opinions émises sont sous l'unique responsabilité des auteurs et ne représentent pas nécessairement les positions du CIRANO ou de ses partenaires.

This paper presents research carried out at CIRANO and aims at encouraging discussion and comment. The observations and viewpoints expressed are the sole responsibility of the authors. They do not necessarily represent positions of CIRANO or its partners. 


\title{
Gas Prices Variations and Urban Sprawl: an Empirical Analysis of the 12 Largest Canadian Metropolitan Areas
}

\author{
Georges A. Tanguay ", Ian Gingras ${ }^{\dagger}$
}

\begin{abstract}
Résumé / Abstract
Nous procédons à une analyse multivariée afin de déterminer les effets d'une hausse du prix de l'essence sur l'étalement urbain dans les 12 plus grandes régions métropolitaines canadiennes pour la période 1986-2006. En tenant compte de variables de contrôle comme le revenu et la population, nous démontrons que des prix de l'essence plus élevés ont contribué significativement à réduire l'étalement urbain. En moyenne, une hausse de $1 \%$ du prix de l'essence a mené à: i) une augmentation de 0,32\% de la population vivant au centre des villes et ii) une baisse de $1,28 \%$ des logements à faible densité. Nos résultats démontent aussi que les hausses des revenus des ménages ont été un facteur significatif ayant contribué à l'étalement urbain.
\end{abstract}

Mots clés : Étalement urbain, prix de l'essence, régions métropolitaines canadiennes.

We conduct a multivariate analysis of the potential impact of higher gas prices on urban sprawl in the 12 largest Canadian Metropolitan Areas for the period 1986-2006. Controlling for variables such as income and population, we show that higher prices of gas have contributed significantly to reduce urban sprawl. On average, a $1 \%$ increase in gas prices has caused: i) a $0.32 \%$ increase in the population living in the inner city and ii) a $1.28 \%$ decrease in low-density housing units. Our results also show that higher incomes have played a significant role in increasing urban sprawl.

Keywords: Urban Sprawl, Gas Prices, Canadian Metropolitan Areas.

\footnotetext{
${ }^{*}$ UQAM, ESG-DEUT, C.P 8888, Succ. Centre-ville, Montreal (Quebec), Canada, H3C 3P8. Fax: 514-9877827; tanguay.georges@uqam.ca

${ }^{\dagger}$ UQAM, ESG-DEUT.
} 


\section{Introduction}

In Canada, urban forms exist that can be associated with urban sprawl, characterized by displacement of the population from the center to the periphery. For example, between 2001 and 2006, for all 33 Census Metropolitan Areas (CMAs), the population of central municipalities ${ }^{1}$ grew by $4.2 \%$, compared with $11.1 \%$ in the peripheral municipalities. ${ }^{2}$

The most recurrent factors identified in the economic literature that can explain urban sprawl are those categorized by Mieszkowski and Mills (1993) under the heading natural evolution. These factors are: i) population; ii) income; iii) transportation costs and iv) agricultural rent (Burchfield et al., 2006; McGibany, 2004; McGrath, 2005; Song \& Zenou, 2006; Wassmer, 2002, 2006, 2008). ${ }^{3}$ The present study concentrates on natural evolution factors, particularly the private transportation cost of individuals. Ceteris paribus, the automobile has reduced the cost of the journey to work because for a given period of time, commuters can now travel longer distances. Over time, people have moved farther from the workplace, often located in the central municipality, and are settling in increasingly distant suburbs.

Nonetheless, for many, the cost of the journey to work can increase, ceteris paribus, with the rising price of gas. For example, the price of a gallon of fuel in the United States (in constant US dollars) rose from $\$ 1.80$ in 2004 to $\$ 4$ in 2008. ${ }^{4}$ If the forecasts of $\$ 200$ per barrel in 2012 are accurate, the real price of gas would reach $\$ 7$ per gallon, and it is likely that this rise in the price of fuel would force Americans to adjust their transport behavior. As an illustration, according to a recent study, a cumulative increase of $280 \%$ in the price of gas between 2004 and the projection of $\$ 7$ per gallon in 2012 should lead to a $16.8 \%$ reduction in miles traveled on American roads, ceteris paribus. ${ }^{5}$

\footnotetext{
${ }^{1}$ The municipality that lends its name to a metropolitan area is regarded as the central municipality.

${ }^{2}$ Statistics Canada (2007). Portrait of the Canadian Population. Catalogue no. 97-550-XIE. Ottawa: Minister of Industry.

${ }^{3}$ Other factors are :i) taxes (Wassmer 2002, 2006, 2008; Brueckner \& Kim, 2003; Song \& Zenou, 2006);

ii) location of different types of industries (Burchfield et al., 2006; Felsenstein, 2002; Gordon \& Richardson, 1996) and iii) climate and topography (Burchfield et al., 2006).

${ }^{4}$ Most of the difference in gasoline prices between Canada and United States is because of taxes. Gasoline taxes vary by state and province and at each national level. When taxes are removed, Canadian and American prices are similar. Source: Natural Resources Canada: http://www.nrcan.gc.ca/eneene/sources/pripri/difdif-eng.php.

${ }^{5}$ CIBC World Markets Inc. 2008. http://research.cibcwm.com/res/Eco/EcoResearch.html.
} 
Therefore, one could assume that the substantial increase in the price of gas could also motivate Canadians to gradually reduce their car use. Indeed, this trend has been observed for several years. The proportion of workers living in the CMAs that travel to work by car, either as drivers or passengers, decreased from $78.1 \%$ in 1996 to $76.8 \%$ in 2006. ${ }^{6,7}$ However, Canadians may be less vulnerable to significant rises in gas prices because the use of public transport is more frequent in the large Canadian metropolitan areas than in their American counterparts. For example, in 2006 the three CMAs with the highest usage rates of public transport were Toronto (22.2\%), Montreal (21.4\%) and Ottawa-Gatineau (19.4\%). By comparison, the metropolitan areas of Boston (11.7\%) and Chicago (11.4\%), which have populations of similar size to these Canadian CMAs, exhibit rates observed in Canadian CMAs of much smaller size such as Halifax (11.9\%) and Victoria (10.2\%). Only the New York City area stands out from among the metropolitan areas in North America, with a rate of $31 \%$ in 2006. Further, the proportion of people in the 33 Canadian CMAs traveling to work by public transport increased from $14.1 \%$ in 1996 to $15.1 \%$ in $2006^{8}$

Urban forms of Canadian cities can be related to urban sprawl in various respects. At first glance, one of the factors explaining this phenomenon is the cost of transportation. Further, the price of gas is mostly increasing, which, we argue, decreases automobile use. $^{9}$ Is there a relationship between the price of gas and urban sprawl in Canadian metropolitan areas? If yes, what is the effect of the rise in the price of gas relative to other factors? Could a substantial increase in the price of gas help attenuate urban sprawl? We answer these questions in the present study and base our analysis on McGibany (2004), who conducts an econometric study of the effects of variations in gas prices on urban sprawl in the United States. He concludes that in the late 1980s, the

\footnotetext{
${ }^{6}$ Statistics Canada. 2008. Place of work and commuting to work, 2006 Census, $\mathrm{n}^{\mathrm{o}} 97-561-\mathrm{X}$ in the catalogue, Ottawa.

${ }^{7}$ This decrease may also be attributable to factors such as environmental awareness, rise in parking meter rates and reserved lanes for carpooling.

${ }^{8}$ Ibid.

${ }^{9}$ In an automobile congestion context, two opposite effects may occur following a rise in gas prices: i) a decrease in mileage for some people (those that used the roads before the increase); ii) an increase in car use by people discouraged by congestion. Thus, although congestion is observed in large cities, the price effect may dominate. This remains to be determined.
} 
states with the highest gas prices had on average, smaller urbanized areas, ceteris

paribus. Similar to other studies (e.g. Song \& Zenou, 2006; Wassmer, 2008), McGibany (2004) analyzes urban sprawl for a given year, although this phenomenon implies a longterm process. Along the same lines as McGrath (2005) and Burchfield et al. (2006), we correct that shortcoming by performing a panel regression analysis using data covering 12 Canadian metropolitan areas over a 20-year period. Aside from the effect of the price of gas on urban sprawl, we take into account factors related to the price of public transit, the values of dwellings, population and incomes. We show that higher prices of gas have contributed significantly to reduce urban sprawl. On average, a $1 \%$ increase in gas prices has caused: i) a $0.32 \%$ increase in the population living in the inner city and ii) a $1.28 \%$ decrease in low-density housing units. We also show that there is a significant relation between more sprawl and higher incomes.

The rest of the paper is divided into four sections. In the next section, we present a typical model of residential location. In section 3, we discuss measures of urban sprawl and present our empirical econometric analysis. We discuss our results in Section 4. The conclusion follows.

\section{A Classical Modeling of Residential Location}

The residential density in cities often varies in two ways: 1) high buildings are built in the center, whereas in the periphery, a larger area per person is occupied and 2) buildings in the center of large cities (in terms of population) are higher than those in the center of small cities. Traditionally, urban economists have explained these phenomena using models based on that of Alonso (1964), Mills (1967, 1972) and Muth (1969). These models state that the further away one moves from the center, the costs of the journey to work increase, whereas the housing costs decrease. Brueckner (1987) summarizes the models of this type to explain the phenomena described above. Brueckner's Muth-Mills model clarifies the effect on land use of changes in exogenous parameters such as population, household income, agricultural rent and transportation cost.

In this model, households aim to maximize their utility according to their choice of residential location, which is a function of land rent, cost of journey to work and of other 
goods and services. The model is illustrated in Figure 1, where the y-axis is in monetary units and provides the housing cost, and the $\mathrm{x}$-axis corresponds to the distance from the Central Business District (CBD). In addition, the straight line $r_{a}$ represents the agricultural rent, whereas the $r_{0}$ and $r_{l}$ curves $\left(r_{i}\right)$ represent the land rent according to various $i$ scenarios.

The land rent is a decreasing function of distance: the farther one is from the CBD, the lower the land rent. $\bar{x}$ is equal to the distance between the CBD and the boundary between the urban area and the rural area. In other words, $\bar{x}$ is the city limits. At the equilibrium, two conditions are met. First, developers encroach on agricultural land for all land used for housing construction. This implies that the city limit $\bar{x}$ is determined when the land rent is equal to the agricultural rent. On the graph, this urban equilibrium is situated at the intersection of the $r_{i}$ and $r_{a}$ curves. The second equilibrium condition is that the urban population be contained within the limit $\bar{x}$.

The theory stipulates that the cost of the journey to work increases as households move away from the center. Hence the housing cost (price per square meter) is a decreasing function of distance. This economic logic is straightforward. By choosing a location at the center, the savings engendered by lower costs of journey to work are reflected in the cost of land, and incidentally in housing. If this were not the case, all households would want to be located in the center. Ultimately, the best location for a household is reflected by a marginal benefit in housing equal to the marginal cost of the journey to work. That being said, the farther households are away from the CBD, the larger the area of their dwelling (floor space). Consequently, the population density, that is the number of people per square meter, is also a decreasing function of distance. ${ }^{10}$ What would this theory predict about a variation in transportation costs?

The slope of the curve of the land rent at any given point is the relation between the variation in housing cost at a central point (all points inside $\bar{x}$ ) and the corresponding

\footnotetext{
${ }^{10}$ In this model, preferences are generally assumed to be identical for all households. However, if this assumption were not made, the location of the household would depend on the relative preferences between housing and transportation. In general, the higher the household income, the larger the housing area consumed even if there are additional consequent costs because of longer travel distance. Thus, lower income households consume less housing area and are located near the center, whereas households with higher income consume a larger housing area and are located farther from the center.
} 
variation in the cost of housing at a distant point from the CBD (all points beyond $\bar{x}$ ). If the transportation costs decrease, the cost of housing is reduced at all points within $\bar{x}$ because the advantages of locating at the center decrease. In the same vein, the cost of housing increases at all points beyond $\bar{x}$. Thus, the $r$ curve becomes less steep and rotates, as illustrated in Figure 1. The $r_{0}$ curve represents the land rent before the decrease in transportation costs, whereas the $r_{l}$ curve represents the land rent after this decrease.

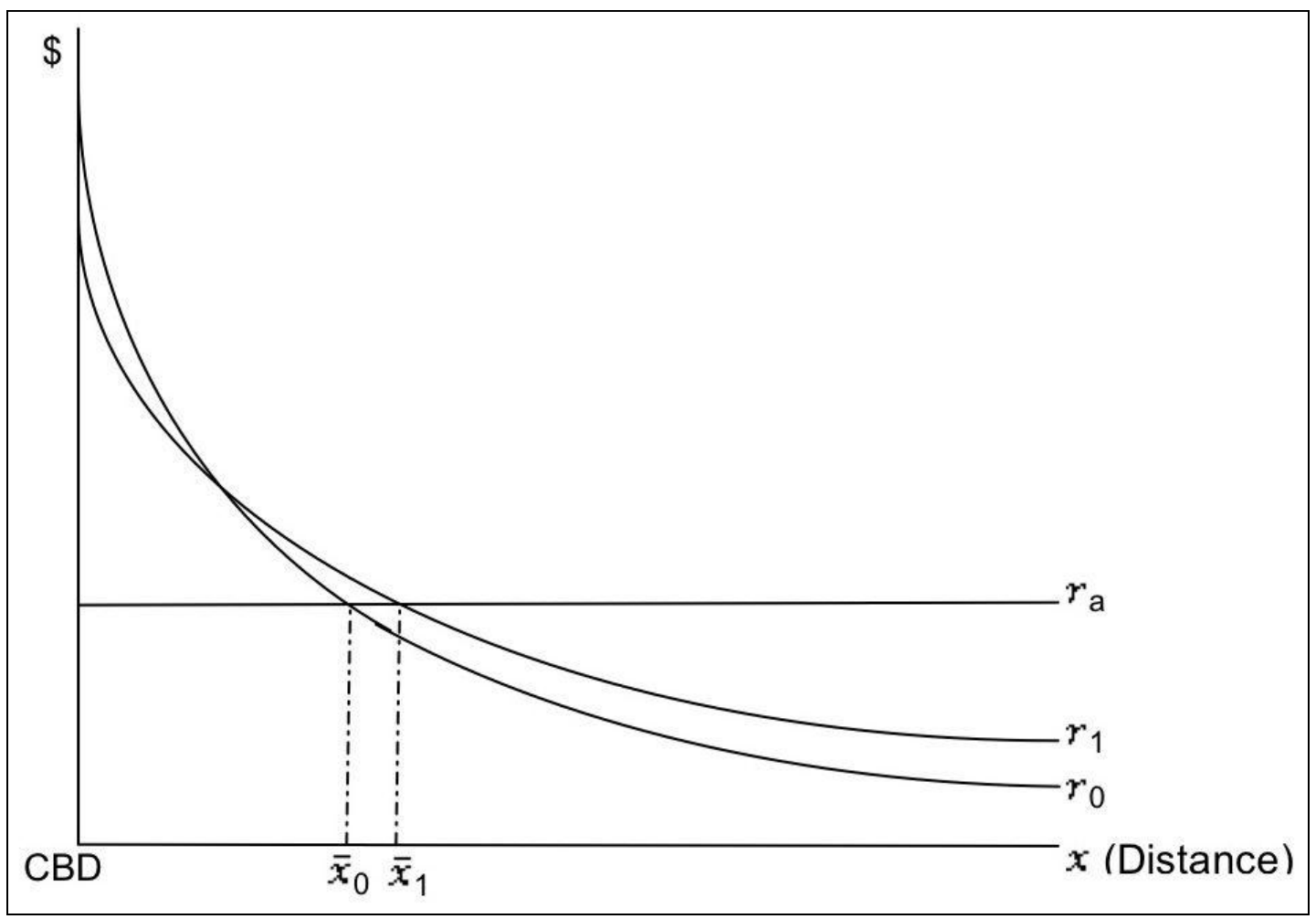

Figure 1

Effect of decrease in transportation cost on land rent and city limits

Some households take advantage of lower land rent by consuming a larger housing area near the CBD, while others benefit from reduced transportation costs by travelling longer distances. The result is an increase in occupied land and extension of the city limits (from $\bar{x}_{0}$ to $\bar{x}_{1}$ ), which leads to urban sprawl. 
According to this model, higher fuel prices should lead to a denser city with less sprawl (and vice versa). ${ }^{11}$ We test this hypothesis in the next section, which describes the empirical study of the relation between urban sprawl and gas prices in the 12 largest Canadian metropolitan areas for the period 1986-2006.

\section{Empirical Analysis}

\subsection{CMAs and Period}

Census Metropolitan Areas (CMAs) serve as geographical observations. Brueckner and Fansler (1983), Galster et al. (2001), Song and Zenou (2006) and Wassmer (2008) analyze urbanized areas in the USA, which differ from metropolitan areas, and which consequently pose problems for the study of urban sprawl. The urbanized area is largely defined based on a minimum density threshold. However, by definition, sprawl occurs at a low density. Therefore, sprawl that would take place below the threshold selected to identify an urbanized area was not measured. Because CMAs include rural and undeveloped areas, we consider them a better measure, within their defined perimeter, to capture all increases in the number of dwellings and the type of housing. Hence, they provide a more precise picture of the location of housing stock compared with existing housing. ${ }^{12}$

Because urban sprawl is a long-term phenomenon, we examine data over a 20 -year period, namely from 1986 to 2006. This period of analysis is based on the availability and reliability of data that originate largely from the five-year census conducted by Statistics Canada. The choice of CMAs is dictated by the availability of data on fuel prices. The study thus covers 12 CMAs: Saint John's (Newfoundland), Halifax (Nova Scotia), Saint John (New Brunswick), Quebec City (Quebec), Montreal (Quebec),

\footnotetext{
11 This is an "average" prediction. As Hanson and Giuliano (2004) assert, different types of reductions in travel cost have different impacts depending on the income group. For example, a reduction in travel time will have a greater effect on high income households because they have a higher time value. Therefore, an improvement in public transport combined with an increase in public transport rates would also have varying effects depending on income. For low income households, the rise in public transit fees could negate the advantages engendered by the reduction in travel time. Consequently, such households would not benefit from an improvement in public transport. However, high income households could benefit from this investment because they are willing to absorb rate increases if it would allow them to reduce their travel time.

${ }^{12}$ Statistics Canada does not define urbanized areas as geographic units; it refers to metropolitan areas exclusively.
} 
Ottawa-Gatineau (Ontario/Quebec), Toronto (Ontario), Winnipeg (Manitoba), Regina (Saskatchewan), Calgary (Alberta), Edmonton (Alberta) and Vancouver (British Columbia).

\subsection{Independent Variables Measuring Urban Sprawl}

The scientific literature proposes several definitions of urban sprawl, which differ between authors and areas of study. McGibany (2004, p. 33) defines urban sprawl as spatial expansion in an urban area: "The rapid spatial expansion area, referred to as urban sprawl, has been analyzed extensively." Several researchers, such as Nechyba and Walsh, refer to the concept of low density: "By sprawl, we will mean the tendency toward lower city densities as city footprints expand" (2004, p. 178). Many authors mention the center-periphery opposition, an omnipresent dichotomy in the literature on urban sprawl (Bussière \& Dallaire (1994), Chapain \& Polèse (2000)). Given the lack of consensus on the definition of urban sprawl, we have performed a global classification of various definitions of urban sprawl in line with Galster et al. (2001). We subsequently choose a subset of these types of definitions that will be measured in this study. Galster et al. (2001) divide measures of urban sprawl into eight dimensions: density, continuity, concentration, clustering, centrality, nuclearity, mixed uses and proximity. Each dimension was tested on 13 American urbanized areas for the year 1990 using geographic information systems (GIS). For the purpose of the analysis, because our study does not use GIS, and based on the availability and reliability of data, we examine three dimensions: centrality, density and proximity. In the next three sub-sections, we present how we measure the dependent variables associated with these three dimensions.

\subsubsection{Measure of Centrality: \% of the CMAs' Population Living in the City Center (Center)}

In line with Bussière and Dallaire (1994), Felsenstein (2002), Gordon and Richardson (1996), McDonald and McMillen (2000), Nechyba and Walsh (2004) and Wassmer (2000, 2002,) we define centrality relative to the percentage of the CMA's population living in the city center. Thus, we take into account the relative weight of the population per urban area. Note that several CMAs have merged their municipalities. However, this is not an obstacle because Statistics Canada has provided data tables that take these 
changes into account. ${ }^{13}$ Consequently, for this variable we have conserved the same geographical limits of CMAs over time. To do so, the 1986 census served as the base data source, and the census subdivisions that are included in later censuses are not considered. ${ }^{14}$

\subsubsection{Measure of Density: \% of Low Density Housing in the CMAs (Density)}

Intuitively, variables used to measure density include those based on population density, such as the number of people in an urbanized area divided by the total area (see Wassmer (2008)). Nonetheless, Galster et al. (2001) contend that these types of variables have two major shortcomings. First, they do not take into account land use, and second, total area should consider not only the area of developed land (as opposed to rivers, infrastructure, etc.). For these reasons, authors such as Galster et al. (2001) and Song and Knapp (2004) estimate that measures related to dwellings are more effective units of measurement because they take into account land use rather than the area of developed land exclusively. Galster et al. (2001) calculate density by the average number of housing units per area (in square miles) of developed land. Song and Knapp (2004) measure density in three ways: median area of single family housing plots in a district (the smaller the area, the higher the density), number of single family dwellings per acre in a district (the higher the number, the higher the density), and median area (in square feet) of floor per single family housing unit in a district (the smaller the area, the higher the density).

\footnotetext{
${ }^{13}$ Complete profiles of all census subdivisions (e.g. central cities, suburban municipalities) whose limits were erased between 1996 and 2006 inclusively, notably because of numerous municipal mergers, are taken into account by Statistics Canada in the table 95F0495XCB01010 (2001 census) and in electronic file 94-581-XCB2006010.ivt (2006 census) (http://ivt.crepuq.qc.ca/recensements/recensement2006/recensPop2006.html). However, despite these adjustments, some data were missing for the CMAs of Halifax, Ottawa-Gatineau and Toronto. Consequently, for the variables proportion of the population of the CMA living in the city center and ratio of average value of housing in the city center to the average value of housing in the CMA, we use a total of 57 observations instead of 60. In addition, we analyze the area of CMA to measure centrality. Regrettably, Statistics Canada maintains that these data are not official. Therefore, we consider density, namely population per square kilometer, to be an unreliable statistic, especially in a longitudinal study. ${ }^{14}$ For example, in 1986 a city such as Saint-Jérôme was not part of the Montreal CMA, although it has been included therein since the 2001 census. The population of this municipality was therefore not considered in the calculation of the proportion. This approach may be seen as introducing a bias, because urban sprawl would be underestimated. However, the $\%$ of the population living in the central area varies minimally using constant geographical limits $(55.21 \%)$ or accounting for changes that occurred between 1986 and 2006 (54.91).
} 
Our measure of density also considers types of dwellings occupied, consistent with Turcotte (2008). ${ }^{15}$ Single, semi-detached and mobile homes represent lower population density, whereas multiple dwellings, condominiums, apartment buildings and row houses are types of housing stock associated with much higher population density. This way of measuring density has the advantage of avoiding calculation of population density, namely the number of residents per square kilometer. Nonetheless, this measure may complicate the analysis because in some CMAs, only part of the territory is inhabited; the rest consists of rivers or space intensive activities such as airports.

To justify the calculation of density by housing type, Turcotte cites Harris (2004), ${ }^{16}$ who concludes that in Canada, the presence of single and semi-detached houses in a district is a major characteristic that differentiates residential suburbs from more urban settings. We thus measure density by using a proportion of all low density housing occupied in the CMA (single and semi-detached houses and mobile homes). Song and Knapp (2004) analyzed this dimension by computing the number of single family homes per acre, which is similar to the method used in this study. ${ }^{17}$

\subsubsection{Measure of Proximity: Median Distance Traveled to Work (Distance)}

As suggested by Galster et al. (2001) and Bussière and Dallaire (1994), we estimate proximity with commuting distance, that is the median distance traveled by residents of the CMA to reach work. Several reasons justify the use of this variable. Statistics Canada notes that to be part of a CMA, other adjacent municipalities must have a high degree of integration with the central urban area, as measured by commuting flows derived from census place of work data. Lastly, as mentioned above, all Canadians central districts are important employment hubs.

We now present the independent variables that will be used in the regression analysis.

\footnotetext{
15 Turcotte, Martin. 2008. “The city/suburb contrast: How can we measure it?, " Canadian Social Trends, Statistics Canada, Catalogue no. 11-008, winter, pp. 2-20.

${ }^{16}$ Harris, R., 2004, How Canada Became Suburban, Toronto, Toronto University Press.

${ }^{17}$ The proportion of low density dwellings is calculated based on housing stock (single and semi-detached houses and mobile homes) occupied in the CMA. However, the 1986 census data are not compatible with those of the other censuses because the category "semi-detached houses" is included in the category "other dwellings." We therefore had to omit 12 observations.
} 


\subsection{Independent Variables ${ }^{18,19}$}

Our objective is to analyze the effect of the cost of the journey to work on urban sprawl, taking into account other factors such as population, income and agricultural rent. Two independent variables are related to the travel cost: i) the price of gas (including and excluding taxes) and ii) the price of public transit. We explain these variables in turn.

\section{Gas Price and Taxes (Total Price, Price and Taxes)}

The variable Total Price gives the gas price at the pump per CMA including taxes. Because taxes vary considerably across provinces, we follow McGibany (2004) and include two other variables to estimate the effects of taxes. ${ }^{20,21}$ The variables Price and Taxes give the gas price excluding taxes and the taxes themselves respectively. We expect that the estimated coefficients of these variables will show that higher gas prices and taxes reduce urban sprawl.

\section{Consumer Price Index of Urban Public Transportation (CPIT)}

When considering the cost of journey to work, Brueckner and Fansler (1983) and McGibany (2004) evaluated the percentage of commuters that use public transport. However, in our study, these data were available only starting from the 1996 census, thus limiting the number of observations. This is why, in line McGrath (2005), who examined the consumer price index of private transportation, we use the consumer price index of urban transportation by bus and subway. This index is available for the provinces only.

\footnotetext{
${ }^{18}$ Variables expressed in monetary terms (gas price, taxes, median household income and housing value) are transformed into constant 2002 dollars with Statistics Canada Table 326-0021.

${ }^{19}$ Like McGrath (2005), we considered introducing a temporal trend variable to capture all the other factors that could contribute to urban sprawl over time. However, we could not use this variable because it created problems of multicollinearity, particularly with the consumer price index of public transport.

${ }^{20}$ Data are available on the Natural Resources Canada website only starting from 1987. Because 1986 is a census year, we hypothesize that the 1987 prices are equivalent to those of 1986 , to obtain a larger data set. Data can be found at http://www.nrcan.gc.ca/eneene/sources/pripri/taxtax-eng.php.

${ }^{21}$ There are two types of fuel taxes. The first type consists of fixed taxes such as the federal government excise tax, at $\$ 0.10$ per liter on gas and $\$ 0.04$ per liter on diesel fuel. In addition, provincial Governments impose fixed taxes on gas that vary considerably between provinces. Lastly, three Canadian municipalities (Vancouver, Victoria and Montreal) add taxes of $\$ 0.06, \$ 0.035$ and $\$ 0.015$ respectively per liter of gas. The second type of taxes is sales taxes such as the federal goods and services tax (GST) of 5\% (except in Nova Scotia, New Brunswick and Newfoundland, where it is replaced by a harmonized sales tax of 13\%). In Quebec, during the study there was an additional sales tax of 7.5\%. The GST/HST applies to the costs of crude oil, refining and marketing costs and margins, the federal excise tax and provincial fuel taxes. For more details on taxes see http://www.nrcan.gc.ca/eneene/sources/pripri/taxtax-fra.php.
} 
Therefore, for the same year, some CMAs have the same value. ${ }^{22}$ We name the associated variable CPIT and we anticipate coefficients that will demonstrate that higher public transit prices lead to more urban sprawl.

\section{Median Household Income (Income)}

To analyze the income effect, different measures are used in the literature. Most authors use income per capita, although Brueckner and Fansler (1983) use average household income. We use median income of households in the CMA, in line with Song and Zenou (2006). We predict that the estimated coefficients of the variable Income will show that higher median household incomes for the CMAs are positively correlated with urban sprawl.

\section{Average Value of Dwellings (Value Ratio)}

Agricultural rent is often estimated by the value of agricultural land. However, because reliable data for this variable were unavailable, we use the ratio of average value of housing in the city center to average value of dwellings in the CMA. We name this variable Value Ratio. The literature asserts that high agricultural rent constrains sprawl. However, we assume that high ratios of average value of housing in the city center to average value of dwellings in the CMA are associated with greater urban sprawl in that people would be willing to commute for longer distances to avoid more expensive housing in the city center.

\section{Total Population (Population)}

In line with Brueckner and Fansler (1983), Burchfield et al. (2006), McGrath (2005), Song and Zenou (2006) and Wassmer (2008), we estimate the effect on sprawl of the total population of an urban area. The associated variable is Population and measures the total population of the CMA. We expect that higher total populations will lead to greater sprawl.

\footnotetext{
${ }^{22}$ Examples include the CMAs of Quebec City and Montreal. In the case of Ottawa-Gatineau, we arbitrarily used the CPI of Ontario.
} 


\subsection{Descriptive Statistics}

Table 1 shows the descriptive statistics of all the variables for the study period: 19862006. Because our main goal is to explain urban sprawl, before we present the regression analysis, we briefly discuss the trends toward urban sprawl in CMAs by presenting the highlights of the three dependent variables selected.

\section{Percentage of the CMAs' Population Living in the City Center}

Two main points can be noted concerning the proportions of the population living in the city center. First, there is a large standard deviation. For instance, almost $15 \%$ of the Toronto CMA lives in the city center, whereas the average for Canadian CMAs is 55\%. In addition, the CMAs of Winnipeg, Regina and Calgary clearly stand out from the other CMAs: i) they have proportions of over $90 \%$ and ii) they demonstrate a stable proportion of their population living in the city center, whereas all the other CMAs have seen decreases in this proportion.

\section{Percentage of Low Density Housing Occupied in the CMA}

The average share of low density housing in the CMAs is 57\%. Only the Vancouver CMA has seen a notable decrease in the proportion of low density housing, from 53\% in 1986 to $38 \%$ in 2006. All the other CMAs have exhibited variations of about $5 \%{ }^{23}$

\section{Median Distance Travelled to Work by CMA Residents}

The median distance travelled to reach work increased in eight out of twelve CMAs between 1996 and 2006. The highest growth occurred in the Calgary CMA, at 9.33\% (1.08\% for the Toronto CMA). The Saint John's and Vancouver CMAs were the only ones with decreases in median distance: i) Saint John's declined from $7.5 \mathrm{~km}$ to $6.9 \mathrm{~km}$ ($8 \%$ ) and ii) Vancouver edged from $7.7 \mathrm{~km}$ to $7.4 \mathrm{~km}$ (- 3.9\%). In the Montreal and Winnipeg areas, the rates remained quite stable, at around 8.1 and $6.1 \mathrm{~km}$ respectively.

\footnotetext{
${ }^{23}$ Vancouver is subject to two dynamics. First, it is a city surrounded by mountains and the sea. Consequently, buildings are higher because of significant land pressure. Further, there have been huge investments in this city, particularly by investors from Hong Kong and China. Many investors bought luxury condos in Vancouver: 1) as a haven in case of political problems; 2) because the prices are increasing, which makes real estate a good investment and 3) for some, to obtain Canadian immigration papers as an investor.
} 
Table 1: Descriptive Statistics

\begin{tabular}{|c|c|c|c|c|c|c|}
\hline Variables & Description and source & $\begin{array}{l}\text { Number } \\
\text { of obs. }\end{array}$ & Mean & $\begin{array}{l}\text { Standard- } \\
\text { deviation }\end{array}$ & Min. & Max. \\
\hline Center & $\begin{array}{l}\text { \% of the population living in CMAs city center } \\
\text { (Statistics Canada Census, } 1991 \text { to 2006). }\end{array}$ & $57 *$ & $55 \%$ & $28 \%$ & $14 \%$ & $95 \%$ \\
\hline Density & $\begin{array}{l}\text { \% of low density housing occupied in the CMA } \\
\text { (Statistics Canada Census, } 1991 \text { to 2006). }\end{array}$ & $48^{*}$ & $57 \%$ & $10 \%$ & $35 \%$ & $73 \%$ \\
\hline Distance & $\begin{array}{l}\text { Median distance in km travelled by CMAs residents } \\
\text { to reach work (Statistics Canada Census, } 1996 \text { to } \\
\text { 2006). }\end{array}$ & $36^{*}$ & 7.0 & 1.3 & 4.4 & 9.4 \\
\hline Population & $\begin{array}{l}\text { Total population of CMA (Statistics Canada } \\
\text { Census, } 1986 \text { to 2006). }\end{array}$ & 60 & 1186159 & 1285170 & 121265 & 5113149 \\
\hline Income & $\begin{array}{l}\text { Median Household Income by CMA (Statistics } \\
\text { Canada Census, } 1986 \text { to 2006). }\end{array}$ & 60 & 49623 & 6122 & 38872 & 61337 \\
\hline Total Price & $\begin{array}{l}\text { Regular gas price at the pump per CMA including } \\
\text { taxes (Natural Resources Canada: } \\
\text { http://www2.nrcan.gc.ca/eneene/sources/pripri/price } \\
\text { s_bycity_f.cfm }\end{array}$ & 60 & 99.92 & 8.01 & 83.07 & 115.07 \\
\hline Gas Price & $\begin{array}{l}\text { Regular gas price at the pump per CMA excluding } \\
\text { taxes (Natural Resources Canada: } \\
\text { http://www2.nrcan.gc.ca/eneene/sources/pripri/price } \\
\text { s bycity f.cfm }\end{array}$ & 60 & 71.32 & 4.75 & 61.50 & 80.83 \\
\hline Taxes & $\begin{array}{l}\text { Average retail taxes on regular gas (Natural } \\
\text { Resources Canada: } \\
\text { http://www2.nrcan.gc.ca/eneene/sources/pripri/price } \\
\text { s_bycity_f.cfm }\end{array}$ & 60 & 28.60 & 5.21 & 17.52 & 39.69 \\
\hline$C P I T$ & $\begin{array}{l}\text { Consumer price index of urban public transportation } \\
\text { (by Province, Statistics Canada: Table 326-0021). }\end{array}$ & 60 & 81.3 & 25.06 & 33.40 & 124.70 \\
\hline $\begin{array}{l}\text { Value } \\
\text { Ratio }\end{array}$ & $\begin{array}{l}\text { Ratio of average value of housing in the city center } \\
\text { to average value of dwellings in the CMA (Statistics } \\
\text { Canada Census, } 1986 \text { to 2006). }\end{array}$ & $57 *$ & 1.03 & 0.10 & 0.90 & 1.28 \\
\hline
\end{tabular}

\subsection{Econometric Model}

We use a log-log model specification, where the values of both the dependent variable $Y$ and the independent variables $X$ are expressed in natural logarithms. Hence, the estimated $\beta$ coefficients will give the elasticity of $Y$ relative to $X$.

We estimate the following equation: $\ln \left(Y_{i t}\right)=\alpha+\beta \ln \left(X_{i t}\right)+\varepsilon_{i t}$, with:

$Y=$ Dependent variable (Center, Density, Distance);

$X=$ Independent variables (Population, Income, Total Price, Gas Price, Taxes, CPIT,

Value Ratio); 
$\alpha=$ Constant;

$\beta=$ Coefficients;

$\varepsilon=$ Error term;

$i=$ Metropolitan areas (1 to 12$)$;

$t=$ Years $(1986,1991,1996,2001,2006)$.

\subsubsection{Estimation Strategy: Generalized Least Squares, Fixed and Random Effects ${ }^{24}$}

We estimated our models based on three methods used in panel regression: generalized least squares (GLS), GLS with fixed effects or random effects. To choose from among these methods, we tested for the presence of individual effects using Breusch-Pagan Lagrange multiplier tests. ${ }^{25}$ Whenever, the presence of individual effects was found, we examine the possibility of adding fixed or random effects.

Fixed effects have the advantage of considering the particular characteristics of metropolitan areas. However, they cause the loss of $N$-1 degrees of freedom, which may make the estimation of the regression coefficients less efficient. For that reason, a model with random effects will provide more efficient estimates and should be used, whenever possible. ${ }^{26}$ To determine if we should estimate a model with fixed or random effects, we performed Hausman tests, which evaluated the null hypothesis that the coefficients estimated by the random effects were the same as those estimated by the fixed effects. When this hypothesis was affirmed, we used a model with random effects.

Finally, given our choices of variables and modeling (see Tables 4.1 to 4.3), we have estimated that endogeneity issues are very unlikely. For instance, regarding the variables of interest (gas price with or without taxes), the dependent variables are local factors that would not influence gas prices. The price of gas is determined mainly by the price of crude oil, which is established on the global market based on variations in supply and

\footnotetext{
${ }^{24}$ See Wooldridge (2002) chapter.10 for a more detailed discussion.

${ }^{25}$ Under the null hypothesis: $H_{0}: \mu_{i}=0$ in the regression $\ln \left(Y_{i t}\right)=\alpha+\beta \ln \left(X_{i t}\right)+\mu_{i}+\varepsilon_{i t}$ where $\mu_{i}$ translates the individual effects, the test confirms that there is a common intercept, and therefore no individual effects. If the null hypothesis is affirmed, the GLS method is recommended.

${ }^{26}$ Regarding random effects, we assume most often that individual effects follow a normal law: $\mu_{i} \sim N\left(0, \sigma^{2}\right)$. Hence, we consider that the error of the model is made up of the usual error specific to an observation $i$, the period $t$ and the error from the random y-intercept.
} 
demand. For instance, Natural Resources Canada ${ }^{27}$ states that the difference in prices between Canada and United States is largely attributable to taxes, which vary across states and/or provinces. Apart from the taxes, Canadian and American products are similarly priced.

Regarding the other independent variables such as the total population of the CMA, median household income and the consumer price index of urban transportation, it is also very unlikely that these variables are influenced by the dependent variables. For example, in all likelihood, the proportion of low density housing in a CMA does not affect the median household income.

We have identified one possibility (in our view weak), where the link of causality between the variables proportion of low density housing and average Value Ratio of housing in the city center to the average value of housing in the CMA might be reversed. The proportion of low density housing is computed based on the type of housing stock (single, semi-detached and mobile homes). However, the average value of the housing may be influenced by the type of housing that predominates in the CMA. For this reason, this variable is not included in equations 2 and $3 .^{28}$

\section{Results}

\subsection{Dependent Variable: \% of the Population Living in City Center}

Table 4.1 shows the results of the model with the dependent variable Center. The BreuschPagan and Hausman tests indicate that it is necessary to estimate a model with fixed effects. In equation 1, we estimate the effects of Total Price and of the control variables Income, CPIT and Value Ratio. Despite a relatively high $\mathrm{R}^{2}(0.58)$, only the coefficient of the variable CPIT is significant. This finding is consistent with McGibany (2004), who also found a coefficient that was not significant for Total Price. He consequently

\footnotetext{
${ }^{27}$ http://www.nrcan.gc.ca/eneene/sources/pripri/difdif-eng.php.

${ }_{28}$ In addition, regressions were done using STATA 10 software, and we applied the robust and cluster options to correct potential problems of heteroskedasticity and autocorrelation of residuals.
} 
introduced the gas price and its taxes separately in another regression. We do the same in equation 2, where the coefficients of the variables Income, Gas Price and CPIT are significant, (whereas the $\mathrm{R}^{2}$ increased to 0.64 ). However, the coefficients of the variables Taxes and Value Ratio are not significant. We consequently retain, in equation 3, only the variables Income, Gas Price and CPIT.

Table 4.1: Dependent Variable: Center (GLS with Fixed Effects ${ }^{1}$; Student-t between brackets)

\begin{tabular}{|c|c|c|c|}
\hline Independent Variable & Equation 1 & Equation 2 & Equation 3 \\
\hline Income & $\begin{array}{l}-0.08 \\
(0.76)\end{array}$ & $\begin{array}{c}-0.23 * * \\
(2.30)\end{array}$ & $\begin{array}{c}-0.23 * * * \\
(2.70)\end{array}$ \\
\hline Total Price & $\begin{array}{c}0.03 \\
(0.32)\end{array}$ & & \\
\hline Gas Price & & $\begin{array}{c}0.32 * * * \\
(2.97)\end{array}$ & $\begin{array}{c}0.32 * * * \\
(3.99)\end{array}$ \\
\hline Taxes & & $\begin{array}{c}0.00 \\
(0.07)\end{array}$ & \\
\hline CPIT & $\begin{array}{c}-0.08 * * * \\
(3.28)\end{array}$ & $\begin{array}{c}-0.08 * * * \\
(3.24)\end{array}$ & $\begin{array}{c}-0.08 * * * \\
(3.41)\end{array}$ \\
\hline Value Ratio & $\begin{array}{c}0.02 \\
(0.17)\end{array}$ & $\begin{array}{c}0.06 \\
(0.40)\end{array}$ & \\
\hline Constant & 0.43 & 0.67 & 0.69 \\
\hline $\begin{array}{l}\mathbf{R}^{2} \\
\text { F-Fisher } \\
\text { Number of observations }\end{array}$ & $\begin{array}{c}0.579 \\
6.11 * * * \\
57\end{array}$ & $\begin{array}{c}0.642 \\
11.49 * * * \\
57 \\
\end{array}$ & $\begin{array}{c}0.639 \\
19.61 * * * \\
57 \\
\end{array}$ \\
\hline Breusch-Pagan test & \multicolumn{3}{|c|}{$\begin{array}{l}\text { H0: } \operatorname{Var}(\mu)=0 \\
\text { Chi-square }(1)=86.02 \\
\text { Prob }>\text { chi-square }=0.000\end{array}$} \\
\hline Hausman test & \multicolumn{3}{|c|}{$\begin{array}{l}\text { H0: Equality of coefficients } \\
\text { Chi-square }(4)=24.92 \\
\text { Prob }>\text { chi-square }=0.000\end{array}$} \\
\hline
\end{tabular}

Statistical significance: $* * *=99 \% ; * *=95 \% ; *=90 \%$.

In equation 3, all the coefficients are significant at the $99 \%$ level. Moreover, all signs confirm our hypotheses. First, the higher the gas prices, the more people tend to live closer to the center, ceteris paribus. The coefficient of Gas Price indicates that a $1 \%$ increase in the gas price corresponds to a $0.32 \%$ increase in the proportion of the population of the CMA living in the city center. Second, relatively low prices of urban 
public transportation favor strong centers in terms of population, ceteris paribus. The estimated coefficient for $C P I T$ implies that a $1 \%$ reduction in the consumer price index of public urban transportation increase the proportion of the population of the CMA living in the city center by $0.08 \%$. Lastly, the coefficient of the Income variable is also negative and shows that higher incomes can contribute to urban sprawl. Other things being equal, a $1 \%$ increase in CMAs' median incomes leads to a $0.23 \%$ decrease in the people living in a city's center.

Finally, the results are quite robust, with the values of the regression coefficients remaining the same between equations 2 and 3. In addition, the $\mathrm{R}^{2}$ remains high at 0.64 .

\subsection{Dependent Variable: \% of Low Density Housing}

Table 4.2 presents the results of the models with the proportion of low density housing stock as a dependent variable. The Breusch-Pagan multiplier test demonstrates that there are no individual effects. In equation 1, the coefficients of the variables Population, Income and Total Price are statistically significant, whereas the coefficients of the CPIT and Value Ratio variables are not. Equations 2 and 3 confirm theses results for the Income and Population variables and show significant negative effects of the gas price without taxes and for the taxes themselves. Further, the $\mathrm{R}^{2}$ remains high across equations. Again we estimated different specifications to assess the relative effects of the components of the total price of gas. The coefficients of the variables related to the gas prices (with and without taxes) are always negative and statistically significant. They reflect a high capacity to reduce the percentage of low density housing. For instance, according to our estimates, a $1 \%$ increase in the gas price (with taxes), is associated with a $1.28 \%$ decrease in the dependent variable. We believe this important effect should be considered by taking into account the Canadian situation. As reflected by our data $(57 \%$ average), the density of Canadian cities is low and one of the lowest in the world. ${ }^{29}$ Therefore, all other things being equal, increasing density is easier than for cities which have already high density levels.

Taxes seem to play a less important role and the only statistically significant coefficient can be found in equation 3 . It shows that if taxes are $1 \%$ higher, low density housing

\footnotetext{
${ }^{29}$ http://atlas.nrcan.gc.ca/auth/english/maps/peopleandsociety/population/population2001/density2001/1.
} 
would be $0.26 \%$ lower. Once again, all the signs of the coefficients affirm our hypotheses.

The estimated coefficients for Income are always positive and confirm our expectations. Ceteris paribus, a $1 \%$ increase in the median household income has lowered the proportion of low density housing by 0.47 to $0.6 \%$. Again, this fairly high effect should be seen considering the Canadian density.

Table 4.2: Dependent Variable: Density (GLS; Student-t between brackets)

\begin{tabular}{|l|c|c|c|}
\hline Independent Variable & Equation 1 & Equation 2 & Equation 3 \\
\hline Population & $-0.17 * * *$ & $-0.17 * * *$ & $-0.15^{* * *}$ \\
Income & $(9.91)$ & $(10.97)$ & $(6.92)$ \\
Total Price & $0.47 * *$ & $0.52 * *$ & $0.60 *$ \\
& $(2.40)$ & $(1.99)$ & $(1.82)$ \\
Gas Price & $-1.28 * * *$ & & \\
Taxes & $(4.67)$ & & \\
CPIT & & $-1.19 * * *$ & \\
& & $(6.32)$ & \\
Value Ratio & -0.06 & $(1.57)$ & $(1.82)$ \\
Constant & $(1.07)$ & & \\
\hline R & 0.29 & & \\
F-Fisher & $(1.20)$ & & \\
Number of observations & 2.77 & 1.63 & -4.19 \\
\hline Breusch-Pagan Test & 0.851 & 0.840 & 0.716 \\
& $164.97 * * *$ & $45.52 * * *$ & $26.97 * * *$ \\
& 45 & 48 & 48 \\
\hline
\end{tabular}

Statistical significance: $* * *=99 \% ; * *=95 \% ; *=90 \%$.

Lastly, the coefficients of the Population variable always show negative signs and they predict that a $1 \%$ total population increase decreases the percentage of low density housing by approximately $0.17 \%$. This seems to contradict our assumption that an increase in the total population of the CMA would increase urban sprawl. 
Nonetheless, this hypothesis is based on the literature concerning econometric modeling, wherein authors analyzed the size of an urban area. However, Burchfield et al. (2006), who measured the percentage of undeveloped land in a square kilometer of average residential development in each American metropolitan area, conclude that cities with relatively low population growth experience more urban sprawl. The negative sign can be explained according to a certain economic logic. The effect of a large (or growing) population may be dual .i) densification (land pressure in built areas, where it becomes increasingly crowded, hence high-density construction) and ii) sprawl (construction of new dwellings in less dense zones). According to the equilibrium between these two dynamics that occur in parallel, we can observe: i) spatial sprawl of the city (more $\mathrm{km}^{2}$ ) and densification (housing $/ \mathrm{km}^{2}$ ), and ii) sprawl and decreasing density. In terms of housing, we may see either an increase or decrease in the percentage of low density housing. The sign of the coefficient of the population variable should therefore be interpreted in a logic of lesser or greater intensity of either of these processes. However, it is quite possible to observe densification and sprawl if the population grows quickly, especially if a portion of the new population crowds at the center (we assume that if people move to the suburbs, they will occupy lower density housing units).

\subsection{Dependent Variable: Commuting Distance}

In our third model, we use commuting distance as the dependent variable (results in Table 4.3). The Breusch-Pagan and Hausman tests demonstrate the need to estimate a model with random effects. Only three variables have statistically significant coefficients for the two estimated equations. The estimated effects are small.

First, for "gas related" variables, only the coefficient of Taxes in equation 2 is noteworthy. A $1 \%$ tax increase leads to a reduction of about $0.2 \%$ in the average commuting distance. For the average commuting distance of our sample, this would lead to a decrease in 14 meters. Second, a 1\% increase in the total population is associated with an average increase of approximately $0.125 \%$ in commuting distance. Therefore, the larger the population, the greater the commuting distance, which favors urban sprawl. Brueckner and Fansler (1983), McGibany (2004), McGrath (2005), Song and Zenou 
(2006) and Wassmer (2008) all conclude that the increase in population contributes to expanding the urbanized areas.

Third, in equation 1, the coefficient of the Value Ratio variable is positive and statistically significant, at $90 \%$. Thus, the higher average values of housing in the city center compared with the CMA overall oblige workers to travel longer distances take advantage of cheaper housing prices in the suburbs. These results support the theory because Brueckner and Fansler (1983), McGibany (2004), McGrath (2005) and Wassmer (2008) found a negative correlation between urban sprawl and high agricultural rent values in the suburbs.

In summary, our results for this third model are mitigated relative to our assumptions. For instance, this is reflected by the coefficients of the Income, Total Price, Gas Price and CPIT variables which are not statistically significant. This may be due to the small number of observations that limits the number of degrees of freedom and make estimation more difficult. 
Table 4.3: Dependent Variable: Distance (GLS with Random Effects; Student-t between brackets)

\begin{tabular}{|c|c|c|}
\hline Independent Variable & Equation 1 & Equation 2 \\
\hline Population & $\begin{array}{l}0.12 * * \\
(2.26)\end{array}$ & $\begin{array}{c}0.13 * * * \\
(2.69)\end{array}$ \\
\hline Income & $\begin{array}{c}0.10 \\
(0.45)\end{array}$ & $\begin{array}{l}-0.22 \\
(0.93)\end{array}$ \\
\hline Total Price & $\begin{array}{l}-0.28 \\
(0.97)\end{array}$ & \\
\hline Gas Price & & $\begin{array}{c}0.17 \\
(1.02)\end{array}$ \\
\hline Taxes & & $\begin{array}{c}-0.21 * * \\
(2.00)\end{array}$ \\
\hline CPIT & $\begin{array}{l}-0.06 \\
(0.65)\end{array}$ & $\begin{array}{l}-0.16 \\
(1.43)\end{array}$ \\
\hline Value Ratio & $\begin{array}{l}0.25 * \\
(1.82)\end{array}$ & $\begin{array}{c}0.16 \\
(1.49)\end{array}$ \\
\hline Constant & 0.79 & 3.29 \\
\hline $\begin{array}{l}\mathbf{R}^{2} \\
\text { Wald chi-square } \\
\text { Number of observations } \\
\end{array}$ & $\begin{array}{c}0.356 \\
122.06^{* * *} \\
33 \\
\end{array}$ & $\begin{array}{c}0,523 \\
116.69 * * * \\
33 \\
\end{array}$ \\
\hline Breusch-Pagan test & \multicolumn{2}{|l|}{$\begin{array}{l}\text { H0: } \operatorname{Var}(\mu)=0 \\
\text { Chi-square }(1)=30.90 \\
\text { Prob }>\text { Chi-square }=0.00\end{array}$} \\
\hline Hausman-test & \multicolumn{2}{|l|}{$\begin{array}{l}\text { H0: Equality of coefficients } \\
\text { Chi-square }(5)=2.14 \\
\text { Prob }>\text { chi-square }=0.8291\end{array}$} \\
\hline
\end{tabular}

Statistical significance: $* * *=99 \% ; * *=95 \% ; *=90 \%$.

\subsection{Discussion}

The analysis of the results clearly demonstrates a negative relation between gas price and urban sprawl in Canadian metropolitan areas. The coefficients of the variables Total Price (model 2), Gas Price (models 1 and 2) and Taxes (model 3) are all statistically significant. This confirms our main hypothesis and clearly establishes the capacity of gas price increases to slow urban sprawl. In addition, we have determined the impact of variations in gas price relative to other factors. Overall, the effect of gas price is substantial given that in a long-term horizon, it is legitimate to believe that gas prices could increase. Obviously, other factors may offset these effects, notably household 
income. The coefficients of the variable Income are statistically significant in models 1 and 2, and demonstrate that increases in income can cause urban sprawl, consistent with much of the literature cited in our study. However, it seems unlikely that income will increase as quickly as gas prices. For instance, this is reflected in Frigon (2007), who, based on Statistics Canada data, shows that Canadians' gasoline purchasing power ${ }^{30}$ has steadily declined since 1986. In short, in our view, a substantial increase in gas prices would amply counterbalance other factors such as household income, to the extent that this increase may contribute to slowing urban sprawl, in conjunction with other factors.

For instance, there is a noteworthy link between the cost of public transportation and urban sprawl. Accordingly, the consumer price index of urban transportation is negatively correlated with the proportion of the population of the CMA living in the city center. Therefore, we believe that lower rates could encourage individuals to use public transit rather than cars, which contributes to reinforcing urban cores in metropolitan areas. $^{31}$ This result is innovative and contrasts with previous findings. For example, Brueckner and Fansler (1983) and McGibany (2004) did not observe a link between percentage of commuters using public transit and urban sprawl.

We also obtained mixed evidence for two variables. First, depending on how urban sprawl is measured, the Population factor may have opposite effects. For example, there is a positive relation between population and median commuting distance, but a negative relation with the proportion of low density housing. Second, the ratio of average value of housing in the city center to average value of dwellings in the CMA does not appear to be a determining factor of urban sprawl in Canadian metropolitan areas. The regression coefficient of this variable is significant only in the first equation of model 3.

Finally, it is worth note that, if generalizations can be made for the 12 metropolitan areas studied, it is nonetheless important to clearly understand the differences between these areas given their limited number and particular characteristics. Thus, although we put the

\footnotetext{
${ }^{30}$ Total disposable income of Canadians divided by the estimated price of gasoline

${ }^{31}$ Several studies have demonstrated that the price elasticity of public transport is relatively low. Consequently, a decrease in rates causes only a very small increase in user volume. Rather, it is the reduction in travel time and the improvement of public transport that would exert a drainage affect on automobile clienteles (O'Sullivan, 2007). This is reflected in the very low value of the regression coefficient (-0.08).
} 
12 areas in a panel and evaluate the presence of individual effects, change in urban forms is slow and problematic. For example, Toronto is a true polycentric metropolis with a CBD (300,000 jobs) and four sub-centers with at least 150,000 jobs each. These subcenters are approximately $30 \mathrm{~km}$ away from the CBD. Conversely, the city of Montreal is mainly mono-centric. ${ }^{32}$ Therefore, sprawl in Montreal (construction far from the center) would undoubtedly lengthen the journey to work because jobs are mainly situated in the city center. However, in Toronto, construction of housing far from the center may bring people working in the large employment centers on the periphery closer to work such that they will not necessarily have a longer commuting distance. Thus, the urban form of each city affects the relation between sprawl and mileage traveled.

\section{Conclusion}

Our study has analyzed the empirical relation between gas price and urban sprawl in the main Canadian metropolitan areas for the period 1986-2006. More specifically, we analyzed urban sprawl relative to three dimensions: centrality, density and proximity. Our results indicate that higher gas prices could contribute to slowing the urban sprawl process. We show that, on average, a $1 \%$ increase in gas prices has caused: i) a $0.32 \%$ increase in the population living in the inner city and ii) a $1.28 \%$ decrease in low-density housing units. Our results also show that higher incomes have played a significant role in increasing urban sprawl.

In general, our analysis indicates that the price of gas exerts a greater influence on urban sprawl than other factors such as household income and population of a major census area. Mainly for that reason, we believe the present study can contribute greatly to the transportation public-policy debates. For instance, regarding private transportation, some support government intervention to lower the gas prices when they increase considerably. However, governments that want to hinder urban sprawl could emphasize the role of a large increase in gas prices.

\footnotetext{
${ }^{32}$ A CBD with 220,000 jobs and a sub-center made up of the cities of Saint-Laurent and Dorval, with 200,000 jobs at 10-15 km from the center, along with sub-centers such as Laval, Longueuil and Anjou, which host about 50,000 jobs each). In addition, in Montreal, jobs outside the centers are located primary around the CBD.
} 
Finally, the study could be improved and serve as a starting point for future research. For instance, the number of observations may be increased over time. It would also be worth using other measures of centrality, density or proximity. Although multivariate analysis with panel data is an important contribution of this study, this methodology could be supplemented by other approaches such as the use of geographic information systems. 


\section{REFERENCES}

Alonso, W. (1964), Location and Land Use: Toward a General Theory of Land Rent. Cambridge, MA: Harvard University Press.

Brueckner, J.K. and D.A. Fansler (1983), "The Economics of Urban Sprawl: Theory and Evidence on the Spatial Size of Cities", The Review of Economics and Statistics, Vol. 65, pp. 479-482.

Brueckner, J.K. (1987), "The Structure of Urban Equilibria: A Unified Treatment of the Muth-Mills Model”, Handbook of Regional and Urban Economics, Vol. II, pp. 821-845.

Brueckner, J.K. and H. Kim (2003), "Urban Sprawl and the Property Tax", International Tax and Public Finance, Vol. 10, pp. 5-23.

Bunting, T., P. Filion and Priston, H. (2002), "Density Gradients in Canadian Metropolitan Region, 1971-96: Differential Patterns of Central Area and Suburban Growth and Change", Urban Studies, Vol. 39, pp. 2531-2552.

Burchfield, M., H.G. Overman, D. Puga and M.A. Turner (2006), "Causes of Sprawl: A Portrait from Space,” The Quarterly Journal of Economics, Vol. May, pp. 587-683.

Bussière, Y. and Y. Dallaire (1994), "Étalement urbain et motorisation: où se situe Montreal par rapport à d'autres agglomérations?" Cahiers de géographie du Quebec, Vol. 38, pp. 327-343.

Chapain, C. and M. Polèse (2000), "Le déclin des centres-villes: mythe ou réalité? Analyse comparative des régions métropolitaines nord-américaines", Cahiers de géographie du Quebec, Vol. 44, pp. 303-324.

Felsenstein, D. (2002), "Do High Technology Agglomerations Encourage Urban Sprawl?” The Annals of Regional Science, Vol. 36, pp. 663-682.

Frigon, M. (2007), "Gasoline Prices and the Impact on Demand Tax", Parliamentary Information and Research Service, PRB 07-55E, 12 pages.

Galster, G., R. Hanson, M.R. Ratcliffe, H. Wolman, S. Coleman and J. Freihage (2001), "Wrestling Sprawl to the Ground: Defining and Measuring an Elusive Concept", Housing Policy Debate, Vol.12, pp. 681-717.

Gordon, P. and H. Richardson (1996), "Employment Decentralization in U.S. Metropolitan Areas: Is Los Angeles an Outlier or the Norm?" Environment and Planning A, Vol. 28, pp. 1727-1743.

Mcdonald, J.F. and D.P. McMillen (2000), "Employment Subcenters and Subsequent Real Estate Development in Suburban Chicago", Journal of Urban Economics, Vol. 48, pp. 135-157. 
Hanson, S. and G. Giuliano (2004), The Geography of Urban Transportation, New York: Guilford Press.

McGibany, J.M. (2004), "Gasoline Prices, State Gasoline Excise Taxes, and the Size of Urban Areas", Journal of Applied Business Research, Vol. 20, pp. 33-41.

McGrath, D.T. (2005), "More Evidence on the Spatial Scale of Cities", Journal of Urban Economics, Vol. 58, pp. 1-10.

Mieszkowski, P. and E.S. Mills (1993), "The Causes of Metropolitan Suburbanization", The Journal of Economics Perspectives, Vol. 7, pp. 135-147.

Mills, E.S. (1967), “An Aggregative Model of Resource Allocation in a Metropolitan area", American Economic Review and Proceedings, Vol. 57, pp. 197-210.

Mills, E.S. (1972), Urban Economics, Glenview, Illinois: Scott Foresman.

Muth, R.F. (1969), Cities and Housing, Chicago: University of Chicago Press.

Nechyba, T. J. et Walsh, R.P. (2004), “Urban Sprawl”, Journal of Economics, Vol. 4, pp. 177-200.

O’Sullivan, A. (2007), Urban Economics, New York, The McGraw-Hill Companies.

Song, Y. and G.J. Knaap (2004), “Is Portland Winning the War on Sprawl?” Journal of the American Planning Association, Vol. 70, pp. 210-225.

Song, Y. and Y. Zenou (2006), "Property Tax and Urban Sprawl: Theory and Implications for US Cities", Journal of Urban Economics, Vol. 60, pp. 519-534.

Wassmer, R.W. (2000), "Urban Sprawl in a U.S. Metropolitan Area: Ways to Measure and a Comparison of the Sacramento Area to Similar Metropolitan Areas in California and the U.S”, Graduate Program in Public Policy and Administration, pp. i-18.

Wassmer, R.W. (2002), "Fiscalisation of Land Use, Urban Growth Boundaries and Noncentral Retail Sprawl in the Western United States", Urban Studies, Vol. 39, pp. 13071327.

Wassmer, R.W. (2006), "The Influence of Local Urban Containment Policies and Statewide Growth Management on the size of United States Urban Areas", Journal of Regional Science, Vol. 46, pp. 25-65.

Wassmer, R.W. (2008), "Causes of Urban Sprawl in the United States: Auto Reliance as Compared to Natural Evolution, Flight from Blight, and Local Revenue Reliance",

Journal of Policy Analysis and Management, Vol. 27, pp. 536-555.

Wooldridge, J. (2002), Econometric Analysis of Cross Section and Panel Data, Cambridge: MIT Press. 